19 Revue d'histoire du XIXe siècle

Société d'histoire de la révolution de 1848 et des

révolutions du XIXe siècle

$10 \mid 1994$

Le silence au XIXe siècle

\title{
Les silences de la vertu
}

Sylvain Rappaport

URL: http://journals.openedition.org/rh19/73

DOI: $10.4000 /$ rh 19.73

ISSN: $1777-5329$

Publisher

La Société de 1848

Printed version

Date of publication: 1 June 1994

ISSN: 1265-1354

Electronic reference

Sylvain Rappaport, «Les silences de la vertu », Revue d'histoire du XIXe siècle [Online], 10 | 1994, Online since 04 September 2008, connection on 19 April 2019. URL : http://journals.openedition.org/rh19/73 ; DOl : $10.4000 /$ rh 19.73

This text was automatically generated on 19 April 2019

Tous droits réservés 


\section{Les silences de la vertu}

\section{Sylvain Rappaport}

\section{ABSTRACTS}

The silence of virtue. In 1819, the baron of Monthyon decides to assign 12 francs to the French Academy in order to revive the "good dees of the people" and to arouse new ones. Eventhtough 351 people, of which 216 women, are jufged as being worthy of the rize during the monarchy of July, the selction isn't an easy task, as the speeches pronounced by the immortels point out, since virtue, far from generating uproars and objections, is often caracterised by the silence that masks it. This muteness has none the less a certain number of advantages. It allows one devoted individual to preserve the self-respect of another; it makes it possible for a person attached by a serious disease to avoid seeing himself as a repulsive being. All the same, this silence is less important than the volontary abstention underlying true modesty. But from 1831, the Academy pronounces its will to put an end to the silence of virtue because of its noxious effects. Indeed, how can one promote "good examples" if nobody talks about them? Virtue therefore needs to expose itself to fight efficiently against "demoralization". Such a struggle couldn't be anodyne, since the Academy's actions contribute to maintaining the silence of the poor people, condemned to virtue.

Le baron de Monthyon décide en 1819 d'attribuer à l'Académie française 12000 francs afin de " tirer de l'oubli les belles actions du peuple et d'en susciter de nouvelles ". Si sous la Monarchie de Juillet, 351 personnes, dont 216 femmes, ont été jugées dignes de recevoir le prix, la sélection des lauréat(e)s n'est pas sans poser problème, comme le soulignent les discours des immortels, puisque la vertu, fort éloignée du tapage et de la réclame, se caractérise a priori par le silence qui la couvre. Le mutisme possède pourtant de multiples avantages. Il permet à la personne que l'on veut protéger par son dévouement de conserver le respect d'elle-même ; il donne la possibilité à un malade qui souffre d'une maladie terrible de ne pas se percevoir comme un objet de répulsion. 
Toutefois, le silence est moins important que l'abstention volontaire qui est l'expression d'une modestie réelle. Mais, à partir de 1831, l'Académie entend combattre le silence de la vertu car celui-ci est nuisible. Comment en effet peut-on diffuser les " bons exemples " si nul n'en parle? La vertu doit donc s'exposer pour lutter efficacement contre la " démoralisation ". Un tel combat ne peut pourtant être anodin, car l'action des académiciens contribue à maintenir silencieux le peuple des pauvres, condamné à la vertu.

INDEX

Mots-clés: Silence, Vertu 